\title{
A Case of Functional Testicular Torsion Caused by In- carcerated Inguinal Hernia in a Newborn
}

Yoo Kyung Choi, MD and Yo Han Ho, MD

Department of Pediatrics, Presbyterian Medical Center, Jeonju, Korea

\section{ABSTRACT}

Testicular torsion in neonates is a urologic emergency with an incidence of 6.1 per 100,000 live births. Incarcerated inguinal hernia is also an emergency with an incidence of approximately $6 \%$ to $31 \%$ in children with inguinal hernia. Functional testicular torsion from an incarcerated inguinal hernia is a rare event in children, often not considered in the initial evaluation. A 19-day-old newborn boy was admitted to our neonatal intensive care unit after visiting a primary clinic. He presented with inconsolable crying and right scrotal swelling. Upon initial physical examination, a hard palpable mass and swelling was found in the inguinoscrotal region, accompanied with redness and warmth of the scrotum. Scrotal ultrasound with color Doppler showed inguinal hernia with strangulation and scanty blood flow to the testis. The patient underwent a right orchiectomy and partial resection of the affected small bowel. Surgical findings confirmed a testicular torsion and incarcerated inguinal hernia with testis with small bowel necrosis. Here, we report a rare case of a newborn with functional testicular torsion as a result of prolonged spermatic cord compression due to incarcerated inguinal hernia.

Key Words: Infant, newborn; Functional testicular torsion; Incarcerated inguinal hernia

\section{서론}

급성 음낭증은 유사한 증상 및 징후를 보이므로 병력 청취나 신체 진찰만으로는 정확한 진단 이 어렵다 ${ }^{1}$. 특히 신생아 급성 음낭증은 통증, 발열, 구토 등의 증상이 거의 없어 조기 진단이 매 우 어려운 질환이기 때문에 고환의 손상을 최소화시키기 위해 신속한 진단과 그에 따른 적절한 치료가 필요하다 ${ }^{11}$.

경우에 따라 즉각적인 수술이 필요할 수 있으며 서혜부 감돈 탈장으로 발생하는 고환 허혈의 경우 소아에서는 드물게 발생하고 초기 평가에서 종종 고려되지 않아 진단 및 치료가 지연되면 영구적인 생식능의 소실이 발생할 수 있달. 따라서 다른 원발성 서혜부 질환이 있는 경우에도 고환 혈류가 완전한지 신속한 확인이 필요하며 결과에 따라 조기 개입이 매우 중요할 수 있다2).

본 저자들은 갑작스런 보챔과 함께 우측 음낭의 부종을 보인 생후 19 일 된 신생아에게서 서혜
Received: 26 August 2021

Revised: 21 October 2021

Accepted: 25 October 2021

Correspondence to: Yo Han Ho, MD

Department of Pediatrics, Presbyterian Medical Center, 365 Seowon-ro, Wan san-gu, Jeonju 54987, Korea

Tel: +82-63-230-1390

Fax: +82-63-230-1490

E-mail: soriyh@nate.com

Copyright(c)

By Korean Society of Neonatology. All right reserved.

This is an Open-Access article distributed under the terms of the Creative Commons At tribution Non-Commercial License (http:// creativecommons.org/licenses/by-nc/4.0), which permits unrestricted non-commercial use, distribution, and reproduction in any medium, provided the original work is pro perly cited. 
부 감돈 탈장과 그에 따른 기능적 고환 염전이 함께 확인된 드문 증 례에 대하여 살펴보고 관련 문헌에 대하여 고찰하고자 한다.

\section{증례}

환아는 재태 연령 40주 4일, 출생체중 4,000 g (>90 percentile)으 로 개인병원에서 자연분만을 통해 출생한 남아로, Apgar 점수는 1 분 9점, 5분 10점으로 분만 손상 없이 양호하였다. 임신 중 특별한 약물 복용 없으며 정기적인 산전진찰을 받았던 건강한 30세 산모의 둘째 아기로 산전 초음파에서 특이 소견은 관찰되지 않았다. 환아 는 개인병원에서 귀가 후 집에서 지내던 중 생후 18 일째 심하게 보 채 개인 소아청소년과에서 진료 후 특이 소견 없어 집에서 경과 관 찰 하였으나 보챔이 지속되고 우측 고환에 부종이 생겨 생후 19 일째 본원 외래로 내원하였다. 외래에서 시행한 신체진찰에서 복부는 전 반적으로 부드럽고 촉지되는 덩어리는 없었으나 우측 서혜음낭부 에서 매우 단단한 약 $2 \times 2 \mathrm{~cm}$ 크기의 압통이 있는 단단한 종괴가 촉 지되었다. 환부 주변은 부종과 함께 적갈색의 발적과 열감이 동반되 어 있었다.

비뇨기과 협진 하에 시행한 음낭 초음파에서는 서혜부 감돈 탈 장과 함께 혈류의 흐름이 없는 경계가 불명확하고 실질내 비균질 성 음영을 보이는 고환 $(8.3 \times 13.1 \mathrm{~mm})$ 이 우측 음낭 내에서 관찰되 었다. 주변의 조직은 전반적으로 붓고 혈류량이 증가하였으며, 좌 측에서는 음낭수종이 관찰되었으나 다른 이상 소견은 관찰되지 않 았다(Figure 1).

수술적 치료를 위하여 본원 신생아중환자실로 입원한 환아는 신체 계측상 체중 4,700 g (>90 percentile), 신장 $59 \mathrm{~cm}$ (>90 percentile), 두위 $37 \mathrm{~cm}$ (>90 percentile)로 측정되었고 생체 징후는 혈압 88/57 $\mathrm{mmHg}$, 맥박 135 회/분, 호흡수 50 회/분, 체온 $36.8^{\circ} \mathrm{C}$ 로 측정되었 다. 혈액 검사에서 백혈구 $6,500 / \mathrm{mm}^{3}$ (중성구 $47.4 \%$, 림프구 $35 \%$ ),
혈색소 $13.8 \mathrm{~g} / \mathrm{dL}$, 적혈구 용적률 $36.6 \%$, 혈소판 $347,000 / \mathrm{mm}^{3}$ 과 전 해질은 정상이었고 C-반응단백질은 $0.81 \mathrm{mg} / \mathrm{dL}$ 이었다.

환아는 전신 마취 하에 우측 서혜부를 절개하여 음낭 종물을 탐색 후 음낭까지 내려가 있는 탈장낭 내에 괴사된 소장의 일부 $($ 약 $5 \mathrm{~cm}$ ) 가 확인되어 이를 절제하였다. 비뇨기과 의사가 수술에 참여하여 적 갈색의 괴사된 고환을 육안으로 확인 후 우측 고환적출술을 시행하 고 외과에서 서혜부 감돈 탈장에 대해 탈장낭의 고위결찰술을 추가 로 시행한 뒤 수술을 종료하였다. 적출한 우측 고환에 대한 현미경 적 소견은 고환 조직 전체에 걸쳐 출혈, 응혈 및 괴사가 일어나 출혈 성 경색 소견에 일치하였고, 적출된 소장 역시 동일 소견으로 관찰 되었다. 환아는 수술 시 반대 측 고환 고정술은 시행하지 않았고, 퇴 원 전 시행한 남은 고환에 대한 음낭 초음파 결과 고환은 음낭 내에 잘 위치하며 정상적인 크기와 음영 및 혈류 흐름을 보였고, 음낭수 종은 소실된 것을 확인할 수 있었다. 이후 환아는 수술 후 특별한 합 병증 소견은 관찰되지 않아 수술 후 5일째 퇴원하였다.

환아는 현재 생후 13 개월로 외래에서 추적 관찰 중이며, 반대 측 고환 꼬임이나 서혜부 탈장 소견 없이 정상적인 성장과 발달을 보이 고 있다.

\section{고찰}

신생아의 급성 음낭증은 신체 진찰 소견이 명확하지 않아 진단이 어렵다 ${ }^{1)}$. 초기 증상으로는 음낭 부종, 발적, 보챔, 울음 등이 있다. 감별 진단으로는 고환 염전, 서혜부 탈장(감돈 또는 교액), 부고환염 또는 고환염, 음낭의 외상, 음낭수종이 있다 ${ }^{2)}$.

서혜부 탈장은 소아에서 흔하게 수술적 치료가 필요한 질환 중 하나이며 소아에서 연 $0.8 \%-4 \%$ 로 발생하며 영아, 특히 미숙아에서 더 높은 비율로 발생한다 ${ }^{3)}$. 대부분 간접형으로 복막초상돌기의 폐 쇄가 완전히 이루어지지 않아 발생되고 방치될 경우 감돈 또는 교

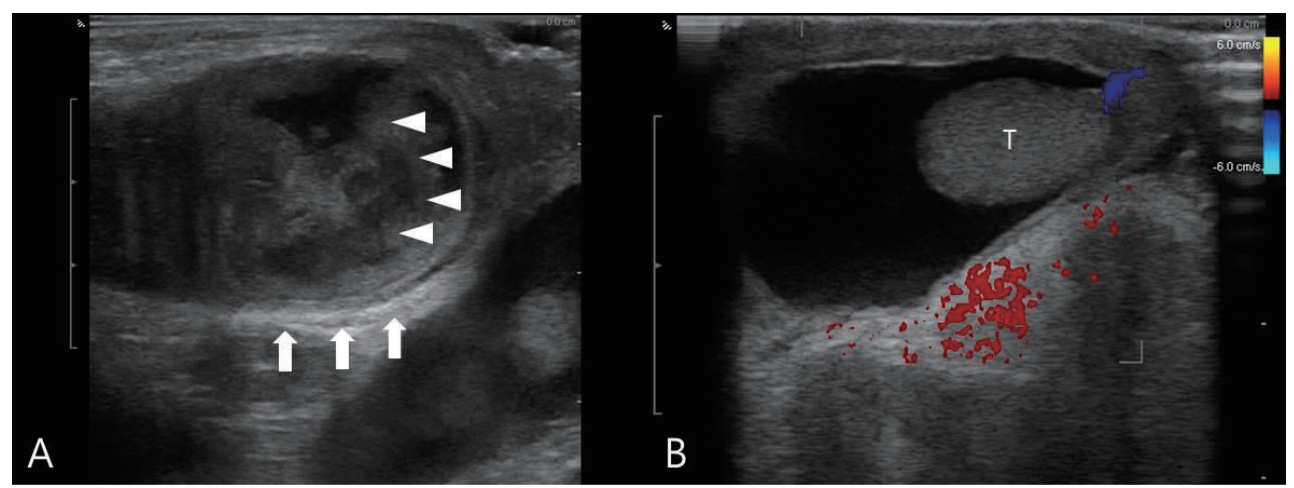

Figure 1. Ultrasound of the scrotum. (A) The right testis had significant heterogeneous parenchyma (arrowheads), and peritesticular tissues were oedemateous (arrows) with absent blood supply. (B) Intact testicular perfusion with moderate hydrocele in the left scrotum. 
액과 같은 합병증이 발생할 수 있어 진단 후 가능한 빠른 교정 수술 이 필요한 질환이다 ${ }^{4}$. 서혜부 탈장이 감돈된 경우 서혜관 내의 혈관 구조물의 압박에 의한 이차적인 장 괴사가 발생할 수 있으며 특별히 남아에게서는 고환 허혈이 발생할 수 있닫․ 서혜부 감돈 탈장으로 인한 장 손상은 $0.1 \%$ 정도의 확률로 나타날 수 있으나, 고환 허혈은 $0.3 \%-15 \%$ 로 더 높은 확률로 발생하며 6개월 미만의 영아는 고환의 측부 혈관 구조가 완성되지 않아 연장아보다 고환 허혈에 더 취약하 닫). 또한 서혜부 감돈 탈장은 마치 고환 염전처럼 보일 수 있다 ${ }^{6}$.

신생아의 고환 염전은 매우 드물며 출생 시 발병률은 약 100,000 명당 6.1명이며, 18세 미만 남아에서는 연 발병률 100,000 명당 3.8 명이닥) 국내에서 Lee 등 ${ }^{8}$ 의 고환 염전의 현황 보고에 따르면 0 세-4세에서 연 100,000명당 1.52명, 25세 미만 남성에서 연 100,000 명당 1.1 명의 발병률을 보였다. 임상 양상은 대개 발열이나 다른 특 이 증상은 없으며 대부분 변색, 부종 등의 이학적 소견에 의해 발견 되며 이것은 급성 음낭증에서 흔히 동반되는 이학적 소견이다'. 도 플러 초음파를 이용한 영상 검사는 진단을 내리는 데 가장 유용하 며, 수술적 치료가 필요한 환자와 보존적 관리로 충분한 환자를 구 별하는 데 도움이 된다 ${ }^{9}$.

고환 염전은 크게 초막외염전(extravaginal), 초막내염전(intravaginal) 두 가지로 분류한다. 이 중에서 신생아기 고환 염전은 청소년 기나 성인의 고환 염전과는 다르게 고환, 부고환, 초막이 정삭을 축 으로 하여 전체적으로 꼬이는 초막외염전이 대부분이다 ${ }^{10)}$. 꼬임의 정도는 180 도에서 720 도 이상까지 다양하고 이 정도와 꼬인 시간 에 따라 고환 염전의 중등도가 달라지게 되며 염전으로 인해 정맥 및 동맥의 혈액공급이 모두 방해되어 결과적으로 고환의 괴저가 발 생한다 ${ }^{10)}$.

고환으로 가는 혈관의 실제 비틀림이 고환 허혈이 발생하는 가장 흔한 원인이지만 종물에 의한 혈관 압박이나 외상성 혈관 파열과 같 은 다른 메커니즘에 의해서도 허혈이 발생할 수도 있달. 원인이 무 엇이든 고환 허혈은 결국 고환의 소실로 이어질 수 있으므로 고환으 로 가는 혈류가 중단되면 기능적 고환 염전이 발생할 수 있다 ${ }^{2)}$.

고환 염전이 발생했을 때 고환을 보존할 수 있는 확률은 20\%-40\% 로, 즉각적인 수술적 개입의 시점에 따라 확률이 달라진다. 모든 정 자발생세포와 세르톨리세포는 허혈 4시간부터 파괴되기 때문에, 고 환의 보존에는 이른 진단이 매우 중요함을 알 수 있다 ${ }^{11)}$. 증상 발생 6 시간 이내 수술할 경우의 고환 보존율은 90\%인 반면에 발생 24시간 이후에 수술 시에는 고환 보존율이 10\% 미만으로 감소하며 2014년 Lee 등 ${ }^{8)}$ 에 따르면 국내에서 0-4세의 고환 보존율은 $75.2 \%$, 전 연령 에서의 고환 보존율은 $75.7 \%$ 를 보였다. 염전된 고환이 소생 가능성 이 없다면 추후 감염의 원인 및 악성 종양의 원인이 될 수 있고, 고환 조직에 대한 항체 생성을 할 수 있어 고환절제술(orchiectomy)이 필 요하다9). 본 증례의 환아는 본원에 내원하여 즉시 비노기과에서 확 진 후 수술까지 약 3시간이 소요되었으나, 내원 전일부터 심한 보챔
을 호소하였던 것으로 보아 염전의 시간은 24 시간 이상이었을 것으 로 추정된다. 이러한 경우 고환의 보존율은 매우 낮으며 증례의 환 아도 육안으로 확인 시 염전된 고환이 이미 괴사되어 고환적출술을 시행하였다.

신생아 고환 염전시 반대 측 음낭수종은 흔하게 관찰되나 이에 대 한 명확한 치료방법에 대한 보고는 거의 없다 ${ }^{12)}$. Kaefer 등르은 이러 한 경우 복막초상돌기를 통한 복강 내 구조물의 탈출이 관찰되지 않 는다면 보존적 치료방법이 신생아의 반대 측 생식능의 손상 가능성 을 최소화할 수 있다고 보고하였다. 본 증례의 환아에서도 반대 측 초음파에서 음낭수종이 관찰되었으나(Figure 1B) 정상적인 고환의 크기와 혈류의 흐름이 관찰되어 보존적 치료를 시행했고, 고환적출 술 후 추시 상 음낭수종이 사라진 것을 초음파를 통해 확인할 수 있 었다.

Waseem 등 ${ }^{2}$ 은 서혜부 탈장의 성공적인 도수 정복 이후 확인된 고환 허혈을 보인 2개월 남아의 증례를 보고하였고, Ozdamar와 Karakus)는 147 명의 서혜부 탈장 환아들 중 10 명(6.8\%)이 합병증으 로 고환 허혈을 보인 증례를 보고하였다. Taylor와 $\operatorname{Strachan}^{13)}$ 은 음 낭 부종을 보인 4 개월 남아가 서혜부 감돈 탈장과 이로 인한 이차적 인 기능적 고환 염전의 증례를 보고하였다.

이와 같이 서혜부 탈장으로 인해 고환으로 가는 혈류가 소실되어 발생한 고환 허혈을 보인 해외 증례들이 보고되었으나 ${ }^{2,5,13)}$ 이와 유 사한 국내 보고는 드물다. 서혜부 감돈 탈장 시 고환 허혈 또는 기능 적 고환 염전이 동반될 수 있고, 이러한 고환 허혈은 영구적인 생식 능 소실을 발생시킬 수 있기 때문에 초음파를 통한 빠른 영상 검사 및 외과, 비뇨기과 의사의 협진 등의 세밀한 주의가 필요하다.

\section{ARTICLE INFORMATION}

\section{Ethical statement}

The Institutional Review Board (IRB) of Presbyterian Medical Center approval for the study was received in July 2021. Retrospective data collection was approved by the IRB of Presbyterian Me dical Center (IRB No. E2021-041). Written informed consent was obtained from all parents.

\section{Conflicts of interest}

No potential conflict of interest relevant to this article was reported.

\section{Author contributions}

Conception or design: Y.K.C., Y.H.H.

Acquisition, analysis, or interpretation of data: Y.K.C., Y.H.H. 
Drafting the work or revising: Y.K.C., Y.H.H.

Final approval of the manuscript: All authors read and approved the final manuscript.

\section{ORCID}

Yoo Kyung Choi https://orcid.org/0000-0001-5184-4711

Yo Han Ho https://orcid.org/0000-0001-7517-955X

\section{Acknowledgments}

None

\section{REFERENCES}

1. Yun JY, Kim MK, Kim MR, Lee KH, Kim KN, Jeong HH. Three cases of acute scrotal disorders in the neonate. J Korean Pediatr Soc 2001;44:841-6.

2. Waseem M, Pinkert H, Devas G. Testicular infarction becoming apparent after hernia reduction. J Emerg Med 2010;38:460-2.

3. Chang SJ, Chen JY, Hsu CK, Chuang FC, Yang SS. The incidence of inguinal hernia and associated risk factors of incarceration in pediatric inguinal hernia: a nation-wide longitudinal population-based study. Hernia 2016;20:559-63.
4. Moss RL, Hatch EI Jr. Inguinal hernia repair in early infancy. Am J Surg 1991;161:596-9.

5. Ozdamar MY, Karakus OZ. Testicular ischemia caused by in carcerated inguinal hernia in infants: incidence, conservative treatment procedure, and follow-up. Urol J 2017;14:4030-3.

6. Wood MJ. Hernia mimicking testicular torsion. Clin Nucl Med 1987;12:142-3.

7. Monteilh C, Calixte R, Burjonrappa S. Controversies in the management of neonatal testicular torsion: a meta-analysis. J Pediatr Surg 2019;54:815-9.

8. Lee SM, Huh JS, Baek M, Yoo KH, Min GE, Lee HL, et al. A nationwide epidemiological study of testicular torsion in Korea. J Korean Med Sci 2014;29:1684-7.

9. Kylat RI. Perinatal testicular torsion. Arch Pediatr 2021;28:75-9.

10. Riaz-Ul-Haq M, Mahdi DE, Elhassan EU. Neonatal testicular torsion; a review article. Iran J Pediatr 2012;22:281-9.

11. Candocia FJ, Sack-Solomon K. An infant with testicular torsion in the inguinal canal. Pediatr Radiol 2003;33:722-4.

12. Kaefer M, Agarwal D, Misseri R, Whittam B, Hubert K, Szymanski $\mathrm{K}$, et al. Treatment of contralateral hydrocele in neonatal testicular torsion: is less more? J Pediatr Urol 2016;12:306.

13. Taylor GM, Strachan CC. Functional testicular torsion secondary to an incarcerated inguinal hernia in a 4-month old: complete recovery at 18-hours. J Surg Case Rep 2021;2021:rjab022. 